\title{
Study on hydrochemical characterization and annual changes of surface water quality for agricultural and drinking purposes in semi-arid area
}

\author{
Milad Mirzaei Aminiyan' ${ }^{1}$ Farzad Mirzaei Aminiyan² Amin Heydariyan $^{3}$
}

Received: 26 October 2015/Accepted: 7 September 2016/Published online: 30 September 2016

(C) Springer International Publishing Switzerland 2016

\begin{abstract}
River water can be known as one of the source of water supply in arid and semi-arid regions. One of the important purposes of hydrology is to ensure water supply in accordance with the quality criteria for agricultural, industrial, and drinking water uses. The main objective of this study was to assess the annual changes of water quality in terms of suitability for drinking and agricultural uses in Givdari River, Rafsanjan, Iran. For this purpose, a dataset of monthly averaged values of water quality variables for the Givdari River was prepared for the years of 2001-2010. Result showed that based on the EC and TDS values, the use of river water for irrigation is suitable and acceptable. The $\mathrm{pH}$ values were suitable for agriculture and drinking uses in all the studied years. The results also indicated that hazard state with respect to $\mathrm{Mg}$ had normal status. According to the correlation coefficient $(r)$, values there are statistically significant $(\alpha=0.01)$ positive correlations between $\mathrm{Cl}$ and $\mathrm{Na}(r=0.981), \mathrm{Cl}$ and $\mathrm{Mg}(r=0.894)$, and $\mathrm{Cl}$ and $\mathrm{SO}_{4}(r=0.872)$. The TDS had good significant correlation with $\mathrm{EC}(r=0.999)$ and all cations and $\mathrm{SO}_{4}$ and $\mathrm{HCO}_{3}$ anions at the 0.01 level. The Total Hardness
\end{abstract}

Milad Mirzaei Aminiyan

miladmir67@yahoo.com

Farzad Mirzaei Aminiyan

m94181029@post.vru.ac.ir

Amin Heydariyan

greengold_2005@yahoo.com

1 Department of Soil Science, Agriculture Faculty, Bu-Ali Sina University, Hamedan, Iran

2 Department of Civil Engineering, Engineering Faculty, Valie-Asr Rafsanjan University, Rafsanjan, Iran

3 Department of Soil Science, Agriculture Faculty, Vali-e-Asr Rafsanjan University, Rafsanjan, Iran
(TH) had good statistically significant correlation with all cations and some anions such as $\mathrm{Cl}$, and $\mathrm{HCO}_{3}$. According to the hydrochemistry diagrams, the main water types during 10 years based on the frequency were $\mathrm{NaCl}$ and $\mathrm{NaHCO}_{3}$.

Keywords Surface water · Irrigation · Drinking · Water quality $\cdot$ Salinity $\cdot$ Alkalinity

\section{Introduction}

Water is the most vital source for sustainability of life. Surface water resource assessments and sustainability considerations are of utmost importance in the arid and semi-arid regions, where water is commonly of critical economic and social significance (Salehi and Hosseinifard 2012). A river is a system comprising both the main course and the tributaries, carrying the one-way flow of a significant load of matter in dissolved and particulate phases from both natural and anthropogenic sources (Awadallah and Yousry 2012). The water quality of a river at any point reflects several major influences, including the lithology of the basin, atmospheric inputs, climatic conditions and anthropogenic inputs (Pradhan et al. 2009). On the other hand, rivers play an important role in assimilation or transporting municipal and industrial wastewater and runoff from agricultural land. Municipal and industrial wastewater discharge constitutes a constant polluting source, whereas surface runoff is a seasonal phenomenon, largely affected by climate within the basin (Zhang et al. 2009). Seasonal variations in precipitation, surface runoff, interflow, groundwater flow and pumped in and outflows have a strong effect on river discharge and, subsequently, on the concentration of salts and nutrients in river water 
(Singh et al. 2004). Therefore, the effective, long-term management of rivers requires a fundamental understanding of hydro-morphological, chemical and biological characteristics. However, due to temporal variations in water quality (which are often difficult to interpret), a monitoring program, providing a representative and reliable estimation of the quality of surface waters, is necessary (Zhang et al. 2012).

Surface water quality is a matter of serious concern today due to in developing countries, rapid population growth coupled with the rate of urbanization and economic development tends to impair the surface water resources and results in high variability for many water quality parameters. Anthropogenic influences (urban, industrial and agricultural activities, increasing exploitation of water resources) and natural processes (changes in precipitation, erosion, and weathering of crustal materials) degrade surface waters and impair their use for drinking, industrial, agricultural, recreation or other purposes (Nouri et al. 2008). Because lakes, reservoirs and rivers constitute the main inland water resources for domestic, industrial and irrigation purposes, it is imperative to prevent and control water pollution and to have reliable information on water quality. Anthropogenic influences and natural processes could each affect surface water quality. In view of the temporal variations in the hydrochemistry of surface waters, regular monitoring programmes are required for reliable estimates of the water quality (Singh et al. 2004).

The evaluation of water quality in most countries has become a critical issue in recent years; especially due to concerns that freshwater will be a scarce resource in the future (Simeonov et al. 2003; Singh et al. 2004; Boyacioglu and Boyacioglu 2007; Papazova and Simeonova 2013). Water quality monitoring is a helpful tool not only to evaluate the impacts of pollution sources but also to ensure an efficient management of water resources and the protection of aquatic life (Mustapha et al. 2014). The qualities of water bodies vary widely depending on the location and environmental factors. Some of the factors determining the qualities of surface waters are the chemical composition of the underlying rocks, soil formations, and the length of time that the water body has been trapped underground (Faniran et al. 2004).

During the last two decades, surface water quality evaluation in different parts of the world has been studied by various researchers (Milovanovic 2007; Bouza-Deaño et al. 2008; Palma et al. 2010; Zhang et al. 2012). Water quality indices provide an easy and simple understandable tool for managers on the quality and possible uses of water; however, an individual quality factor alone is not enough to evaluate the water quality because it could be restrictive, and sometime it could give an unfavorable qualification. The water quality assessment is mostly based on hydrochemical analysis (Shakeri et al. 2014), and also, the quality of surface water is commonly determined by selected physicochemical analyses of water samples collected to represent the water body (Aris et al. 2013). as the hydrochemical study reveals water quality to determine water suitability for drinking, agricultural, and industrial purposes. Surface water often consists of seven major chemical elements, e.g., $\mathrm{Ca}^{2+}, \mathrm{Mg}^{2+}, \mathrm{Cl}^{-}, \mathrm{HCO}_{3}{ }^{-}, \mathrm{Na}^{+}$, $\mathrm{K}^{+}$, and $\mathrm{SO}_{4}{ }^{2-}$ (Seeboonruang 2012). The chemical parameters of water play significant roles in classifying and assessing its quality (Zhang et al. 2012).

The importance of the surface and ground water resources in the arid and semi-arid areas should not be underestimated because they are the only water resource for drinking and agricultural purposes not only for the people living in this areas but also for those who live in the surrounding areas (Baghvand et al. 2010). Despite the lack of alternative water sources, the surface water hydrogeochemistry of the region remains poorly understood. One of the most severe problems in arid and semi-arid regions is the high concentration of salts in water resources. The excessive and inefficient use of surface water in such systems may lead to the salinization of water and soils. During recent years, changes in the quality of ground and surface water have been reported for different areas of the world, such as southeastern Spain, southern Texas, and northern Chihuahua (Salehi and Hosseinifard 2012). Consequently, water quality and its management have received much attention in developing countries. Salinization and decreasing water levels increase the need for a comprehensive understanding of the surface water system that would help better management of the resource. The chemical composition of surface water is controlled by many factors that include composition of precipitation, geological structure, mineralogy of the watersheds and aquifers, and geological processes within the aquifer (Andre et al. 2005). The interaction of all factors leads to various water types. Increased knowledge of geochemical evolution of water resources in arid and semi-arid regions could lead to improved understanding of hydrochemical systems in such areas, leading to sustainable development of water resources and effective management of surface water resource.

From an agricultural perspective, the principal variables to be evaluated in the classification of water quality are (1) the concentrations of dissolved solids and salts, (2) the relative presence of sodium $\left(\mathrm{Na}^{+}\right)$, (3) the carbonate $\left(\mathrm{CO}_{3}{ }^{2-}\right)$ and bicarbonate $\left(\mathrm{HCO}_{3}{ }^{-}\right)$contents, and (4) the concentrations of other specific ions, such as chloride and boron. The main problem with a high sodium concentration is its effects on chemical and physical properties of soils. It contributes directly to the total salinity and toxicity of sensitive crops and has negative effects on the structure of 
the soil that reduces its capacity to conduct water and air through its profile (Salehi and Hosseinifard 2012). This, in turn, decreases soil fertility, because in addition to affecting aeration, it also increases $\mathrm{pH}$ and reduces the availability of iron (Fe) and zinc ( $\mathrm{Zn})$ (Baghvand et al. 2010).

Iran is located in a semi-arid area with an average annual precipitation less than one-third of that of the world. Furthermore, spatial and temporal distributions of the regional precipitation are not integrated. Iran is one of the twenty-seven countries that are likely to face increasing water shortage crises between now and 2025 unless action is taken to reduce current water consumption (Bidhendi et al. 2007). Accordingly, lack of water resources is observed in most parts of Iran, therefore management of water resource is necessary in this country. Despite the importance of water resources (surface and ground waters) in Iran, little is known about the natural phenomena that govern the chemical composition of these water resources or anthropogenic factors that presently affect them (Jalali 2010).

In the present study, a large data matrix, obtained during ten years (2001-2010) monitoring program, is subjected to hydrochemical analysis to extract information about the identification of water quality variables responsible for temporal variations in water quality of the Givdari River. The main objective of this study was hydrochemical assessment and evaluation annual changes of suitability water quality for drinking and agricultural uses in Givdari River.

\section{Materials and methods}

\section{Study area}

The Givdari River basin is located between latitudes $56^{\circ} 03^{\prime} 46^{\prime \prime} \mathrm{N}$ and longitudes $30^{\circ} 0^{\prime} 32^{\prime \prime} \mathrm{E}$, in the Southwest Rafsanjan Plain, Iran (Fig. 1). The Givdari river is one of the important permanent rivers in this region. It originates from a natural reservoir in mountain areas $2129 \mathrm{~m}$ above the mean sea level near the town of Bardsir in Kerman province, Iran. This river after traversing over $30 \mathrm{~km}$, discharges into the Shoor River, which is located in Northwestern of Rafsanjan Plain, Iran (outlet). The river is usually used as a supply of water for agriculture, cattle breeding, domestic and industrial activities. In addition, the river receives domestic and industrial wastewater from Sarcheshmeh copper mine minor settlements along the bed. Discharges into the Givdari River vary from 0.12 to $1.14 \mathrm{~m}^{3} \mathrm{~s}^{-1}$ at different years probably due to low precipitation and inputs from the tributaries or natural recharge of the stream (Jamshidzadeh and Mirbagheri 2011). The river passes along its course through limestone, marl, gypsum and sandstone soils, which are the main

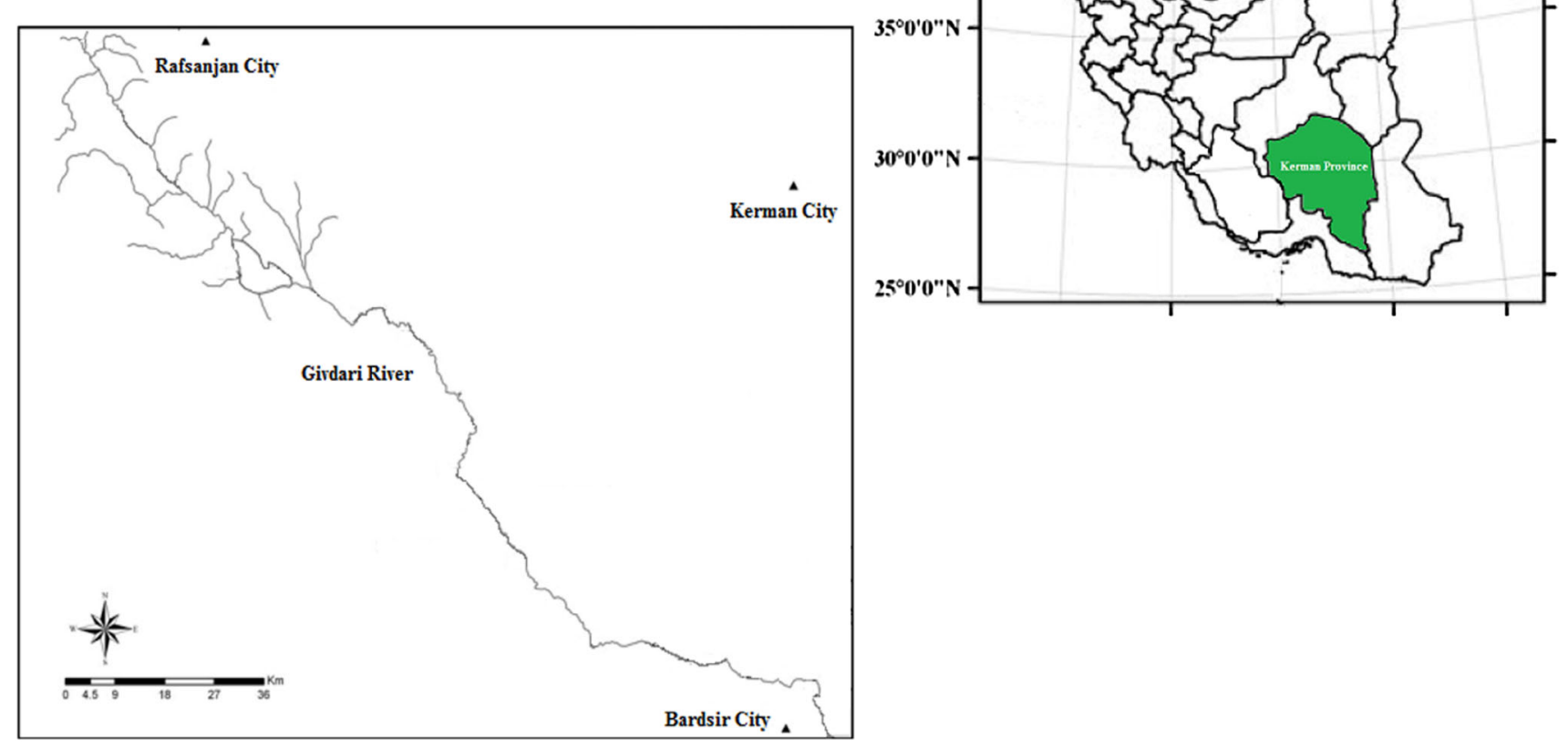

Fig. 1 The location of the Givdari River in Rafsanjan Plain, Kerman Province, Iran 
contributors to the high levels of minerals in the river water. For one decade (from 2001 to 2010), during the summer months, the maximum annual temperature is up to $44{ }^{\circ} \mathrm{C}$ and during the winter months the minimum temperature drops to $2{ }^{\circ} \mathrm{C}$. The mean annual precipitation of this region is less than $150 \mathrm{~mm}$. The mean annual potential evapotranspiration is more than $3000 \mathrm{~mm}$. The most important economic activity of this area is pistachio orchard (Hosseinifard and Aminiyan 2015).

\section{Water sampling and analysis}

The data used in this study is part of the database maintained by the water resources authority of Kerman province, the Iranian Power and Energy Ministry. This monitoring sampling strategy was designed to cover a wide range of hydrochemical parameters. The monitoring program collects samples each month at the sampling station. The annual averages from 2001 to 2010 were available in this study. The important major cations and anions in water samples were analyzed following a standard method (APHA 2008) (Table 1). Electrical Conductivity (EC) and $\mathrm{pH}$ values were measured in situ using a portable conductivity and $\mathrm{pH}$ meter, respectively. Other chemical indices were derived from the measured water quality parameters. The formula adopted and

Table 1 Methods adopted for water quality analysis in Givdari River

\begin{tabular}{lll}
\hline Quality parameter & Symbol & Method used $^{\mathrm{a}}$ \\
\hline $\mathrm{pH}$ & $\mathrm{pH}$ & Potentiometric $\left(1: 2.5 \mathrm{H}_{2} \mathrm{O}, \mathrm{v} / \mathrm{v}\right)$ \\
Electrical conductivity & $\mathrm{EC}$ & Conductometery $\left(1: 2.5 \mathrm{H}_{2} \mathrm{O}, \mathrm{v} / \mathrm{v}\right)$ \\
Calcium & $\mathrm{Ca}^{2+}$ & EDTA $(0.05 \mathrm{~N})$ titrimetric \\
Magnesium & $\mathrm{Mg}^{2+}$ & EDTA (0.05 N) titrimetric \\
Sodium & $\mathrm{Na}^{+}$ & Flame photometric \\
Potassium & $\mathrm{K}^{+}$ & Flame photometric \\
Chloride & $\mathrm{Cl}^{-}$ & Titration using 0.05 N AgNO \\
Sulphate & $\mathrm{SO}_{4}{ }^{2-}$ & Spectro Photometric \\
Bicarbonate & $\mathrm{HCO}_{3}{ }^{-}$ & Titration (with 0.01 $\left.\mathrm{N} \mathrm{H}_{2} \mathrm{SO}_{4}\right)$ \\
\hline
\end{tabular}

a Source: Pansu and Gautheyrou (2006) sources for the calculated water quality indices are summarized in Table 2.

\section{Data statistical analysis}

The statistical analyses carried out using MINITAB (version 16) and Pearson's correlation was employed to examine the relationships among variables [0.01 level (2tailed)]. Also hydrochemical graphs (e.g., Richards, Piper, Durov, Stiff and Schoeller Diagrams) were depicted by Rockworks (version 14) and AqQA (version 1.1.1) softwares.

\section{Results and discussion}

The chemical compositions of the river water samples were analyzed and the results were presented in average values for each year (Table 3). Based on this table, the maximum and the minimum values of EC were observed on 2001 and 2002, respectively. According to the degree of restriction on the use for EC, based on FAO guidelines, it is severe $\left(\mathrm{EC}<3 \mathrm{dS} \mathrm{m}^{-1}\right)$ in all years for agricultural practices (Ayers and Westcot 1985). The maximum permissible value of EC for drinking water is $1.4 \mathrm{dS} \mathrm{m}^{-1}$ (WHO 2011). The assessment of EC values in Givdari River for ten years showed that the use of this water was acceptable and suitable for agriculture purpose (Fig. 2a). However, according to the WHO (2011) guidelines for EC value, water quality of Givdari River for drinking is higher than the prescribed limit for this purpose all years except for 2002. The results of Hosseinifard and Aminiyan (2015) supported these results. Water salinity is usually measured by the TDS (total dissolved solids) or the EC (electric conductivity). Water with high salinity is toxic to plants and poses a salinity hazard. Soils with high levels of total salinity are called saline soil. High concentrations of salt in the soil can result in a "physiological" drought condition. That is, even though the field appears to have plenty of moisture, the plants wilt because the roots are unable to absorb the water (Gowing et al. 2009; Liu et al. 2012).

Table 2 Water quality parameter estimation methods from measured parameters

\begin{tabular}{llll}
\hline Quality parameters & Symbol & Formula adopted & Reference/source \\
\hline Total dissolved solids & TDS & TDS $=640 \times \mathrm{EC}($ for EC $<5 \mathrm{dS} / \mathrm{m})$ & Dinka (2010) \\
Sodium adsorption ratio & SAR & TDS $=800 \times \mathrm{EC}$ (for EC $>5 \mathrm{dS} / \mathrm{m})$ & Pansu and Gautheyrou (2006) \\
Magnesium Hazard & $\mathrm{SAR}=\frac{\mathrm{Na}}{\sqrt{\frac{\mathrm{Ca}+\mathrm{Mg}}{2}}}$ & $\mathrm{MH}=\frac{\mathrm{Mg}^{2+}}{\mathrm{Ca}^{2+}+\mathrm{Mg}^{2+}} \times 100$ & Raghunath (1987) \\
Total hardness & $\mathrm{MH}$ & $\mathrm{TH}=\left(\mathrm{Ca}^{2+}+\mathrm{Mg}^{2+}\right) \times 50$ & (Sawyer et al. 2003) \\
\hline
\end{tabular}

All the ionic concentrations are in meq $1^{-1}$ 
Table 3 Summary statistics of chemical compositions of major ions $\left(\mathrm{mg}^{-1}\right)$ for ten years water sampling in Givdari River

\begin{tabular}{|c|c|c|c|c|c|c|c|c|c|c|c|c|}
\hline Year & & $\begin{array}{l}\mathrm{Ca} \\
\mathrm{mg} 1^{-1}\end{array}$ & $\begin{array}{l}\mathrm{Mg} \\
\mathrm{mg} \mathrm{l}^{-1}\end{array}$ & $\begin{array}{l}\mathrm{Na} \\
\mathrm{mg} \mathrm{1^{-1 }}\end{array}$ & $\begin{array}{l}\mathrm{HCO}_{3} \\
\mathrm{mg}^{-1}\end{array}$ & $\begin{array}{l}\mathrm{SO}_{4} \\
\mathrm{mg} \mathrm{l}^{-1}\end{array}$ & $\begin{array}{l}\mathrm{Cl} \\
\mathrm{mg} 1^{-1}\end{array}$ & $\begin{array}{l}\text { TDS } \\
{\mathrm{mg} 1^{-1}}^{-1}\end{array}$ & $\begin{array}{l}\mathrm{EC} \\
\mathrm{dS} \mathrm{m} \mathrm{m}^{-1}\end{array}$ & $\mathrm{pH}$ & SAR & $\begin{array}{l}\mathrm{TH} \\
\mathrm{mg} \mathrm{CaCO} \\
31^{-1}\end{array}$ \\
\hline \multirow[t]{4}{*}{2001} & Mean & 107.71 & 60 & 309.51 & 333.76 & 312 & 418.82 & 1506.57 & 2.25 & 7.4 & 5.81 & 519.29 \\
\hline & SD & 47.3 & 36.7 & 264.9 & 136.7 & 191.3 & 376 & 948.8 & 1.46 & 0.4 & 4 & 268.2 \\
\hline & $\operatorname{Max}$ & 146 & 116 & 633 & 506 & 480 & 922 & 2529 & 3.89 & 8 & 10 & 850 \\
\hline & Min & 34 & 13 & 30 & 159 & 48 & 18 & 263 & 0.40 & 7 & 1 & 145 \\
\hline \multirow[t]{4}{*}{2002} & Mean & 64.86 & 33.77 & 169.87 & 311.97 & 141.94 & 188.90 & 777.14 & 1. 30 & 7.7 & 3.96 & 302.86 \\
\hline & SD & 23.4 & 19.2 & 161.8 & 144.5 & 72.7 & 176.7 & 502.4 & 0.83 & 0.2 & 3.3 & 118.5 \\
\hline & Max & 100 & 73 & 501 & 543 & 288 & 514 & 1704 & 2.84 & 8 & 11 & 510 \\
\hline & Min & 28 & 17 & 39 & 153 & 72 & 21 & 272 & 0.45 & 8 & 1 & 140 \\
\hline \multirow[t]{4}{*}{2003} & Mean & 89.14 & 33.60 & 185.64 & 431.36 & 117.94 & 197.51 & 898.14 & 1.41 & 7.3 & 3.81 & 362.86 \\
\hline & SD & 23.2 & 19.6 & 109.2 & 167.8 & 53.2 & 118.4 & 401.6 & 0.61 & 0.3 & 2 & 114.6 \\
\hline & Max & 122 & 62 & 315 & 659 & 192 & 347 & 1450 & 2.23 & 8 & 6 & 560 \\
\hline & Min & 68 & 13 & 62 & 275 & 58 & 50 & 450 & 0.69 & 7 & 2 & 225 \\
\hline \multirow[t]{4}{*}{2004} & Mean & 78 & 46.80 & 188.60 & 419.38 & 139.20 & 220.68 & 977 & 1.50 & 7.5 & 3.67 & 390 \\
\hline & SD & 32.7 & 25.9 & 198.6 & 204.6 & 102.1 & 245.2 & 752.6 & 1.16 & 0.3 & 3.4 & 187 \\
\hline & Max & 116 & 71 & 460 & 628 & 269 & 560 & 1937 & 2.98 & 8 & 8 & 585 \\
\hline & Min & 46 & 20 & 35 & 232 & 53 & 39 & 373 & 0.57 & 7 & 1 & 225 \\
\hline \multirow[t]{4}{*}{2005} & Mean & 104 & 48 & 298.54 & 506.30 & 232.32 & 320.47 & 1315.80 & 2.02 & 7.5 & 6.05 & 460 \\
\hline & SD & 69.9 & 23.6 & 168.4 & 250.2 & 85.8 & 249.9 & 658.9 & 1.01 & 0.4 & 2.2 & 271.9 \\
\hline & Max & 220 & 84 & 527 & 854 & 331 & 709 & 2275 & 3.50 & 8 & 8 & 900 \\
\hline & Min & 30 & 18 & 115 & 153 & 96 & 78 & 605 & 0.93 & 7 & 3 & 150 \\
\hline \multirow[t]{4}{*}{2006} & Mean & 72.44 & 40.53 & 198.57 & 363.29 & 142.40 & 237.91 & 968.22 & 1.49 & 7.6 & 4.34 & 350 \\
\hline & SD & 17.5 & 28.5 & 138.3 & 160.5 & 70.3 & 193.9 & 536.8 & 0.82 & 0.5 & 2.6 & 149.6 \\
\hline & $\operatorname{Max}$ & 100 & 96 & 391 & 555 & 264 & 525 & 1638 & 2.50 & 9 & 8 & 580 \\
\hline & Min & 52 & 17 & 23 & 183 & 53 & 35 & 344 & 53 & 7 & 1 & 200 \\
\hline \multirow[t]{4}{*}{2007} & Mean & 103.20 & 43.68 & 305.44 & 419.68 & 260.64 & 346.35 & 1314.20 & 2.02 & 7.7 & 6.23 & 440 \\
\hline & SD & 22.3 & 19 & 156 & 76.3 & 111.8 & 176.6 & 449.2 & 0.69 & 0.4 & 2.8 & 97.8 \\
\hline & $\operatorname{Max}$ & 140 & 72 & 518 & 488 & 437 & 603 & 1950 & 3.00 & 8 & 10 & 600 \\
\hline & Min & 72 & 18 & 150 & 275 & 120 & 142 & 787 & 1.21 & 7 & 3 & 300 \\
\hline \multirow[t]{4}{*}{2008} & Mean & 84.62 & 45.42 & 260.61 & 405.42 & 176.12 & 320.14 & 1213.85 & 1.84 & 7.5 & 5.19 & 400.77 \\
\hline & SD & 34.5 & 25.8 & 193.3 & 176.2 & 116.5 & 251.4 & 708.6 & 1.07 & 0.3 & 3.4 & 163.8 \\
\hline & $\operatorname{Max}$ & 160 & 92 & 529 & 732 & 451 & 709 & 2145 & 3.25 & 8 & 10 & 600 \\
\hline & Min & 40 & 18 & 23 & 183 & 48 & 18 & 270 & 0.41 & 7 & 1 & 175 \\
\hline \multirow[t]{4}{*}{2009} & Mean & 86.60 & 50.04 & 314.41 & 409.31 & 193.92 & 404.84 & 1365.30 & 2.07 & 7.5 & 6.29 & 425 \\
\hline & SD & 17 & 27.5 & 179.2 & 101.2 & 109 & 255.3 & 631.1 & 0.95 & 0.3 & 2.8 & 143.4 \\
\hline & Max & 120 & 84 & 552 & 549 & 384 & 674 & 2059 & 3.12 & 8 & 10 & 600 \\
\hline & Min & 60 & 12 & 69 & 232 & 67 & 60 & 422 & 0.64 & 7 & 2 & 200 \\
\hline \multirow[t]{4}{*}{2010} & Mean & 75.82 & 41.02 & 211.39 & 359.35 & 147.49 & 263.62 & 987.27 & 1.49 & 7.7 & 4.18 & 360.45 \\
\hline & SD & 30.4 & 32.1 & 218.4 & 160.2 & 138 & 288.1 & 775.5 & 1.17 & 0.2 & 3.5 & 202.8 \\
\hline & Max & 140 & 89 & 593 & 616 & 442 & 709 & 2158 & 3.27 & 8 & 10 & 710 \\
\hline & Min & 52 & 12 & 35 & 165 & 14 & 35 & 343 & 0.52 & 7 & 1 & 195 \\
\hline
\end{tabular}

$S D$ standard deviation, Max maximum, Min minimum

The $\mathrm{pH}$ of the water is also an indicator of its quality, and normally ranges from 6.5 to 8.4 (Ayers and Westcot 1985). Based on FAO prescribed guidelines, the $\mathrm{pH}$ values were suitable and had optimal level in all years for agriculture purpose and it created no problem for growing of different plants and cropping. The results showed that, the $\mathrm{pH}$ value on 2002, 2007 and 2010 was higher, and its value on 2003 was lower than the other years (Fig. 2b). The pH values of water in the Givdari River varied between 7.3 and 7.7, indicating slightly alkali water. The achieved results 

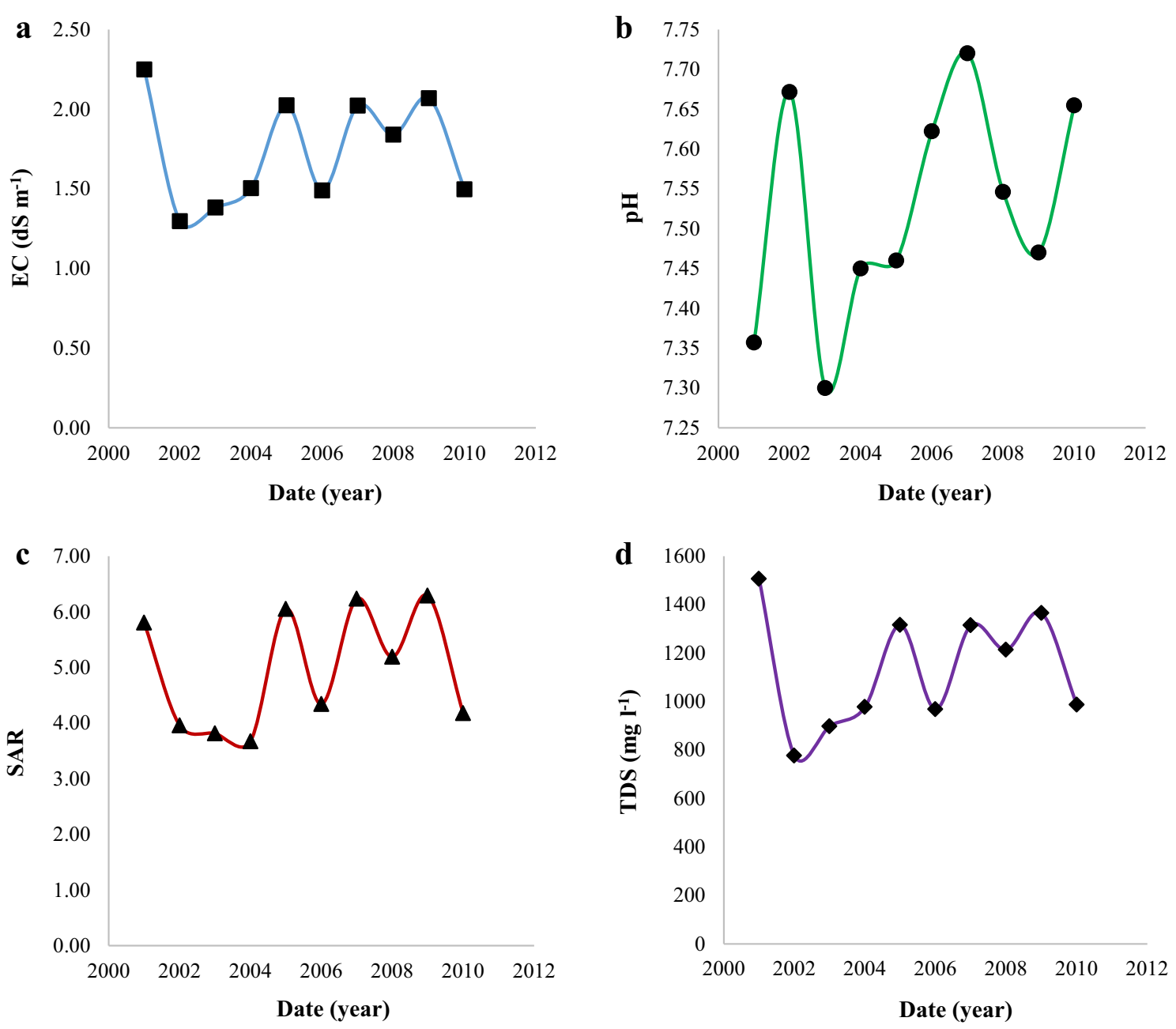

Fig. 2 Ten years time trend of a EC (dS/m), b pH, c SAR, and d TDS (mg/l) parameters value in Givdar River

by Mortazavi et al. (2014) and Hosseinifard and Aminiyan (2015) supported these results. According to the WHO guidelines, $\mathrm{pH}<6.5$ or $>9.2$ would markedly impair the potability of drinking water (WHO 2011). The pH usually has no direct impact on human health; however, higher value of $\mathrm{pH}$ can increase the scale formation in water pipes and also reduce disinfection potential of chloride (Seth et al. 2014).

The SAR is sodium hazard index for water quality. It is obvious from Fig. 2c that higher values of SAR observed in 2005 (6.05), 2007 (6.23) and 2009 (6.29), respectively, and the minimum of SAR values observed in 2006 (4.34) and 2010 (4.18), respectively. According to the established guideline by WHO (2011), the value of $200 \mathrm{mg} \mathrm{l}^{-1}$ recommended for sodium $\left(\mathrm{Na}^{+}\right)$concentration based on taste considerations and concentrations in excess of $200 \mathrm{mg} \mathrm{l}^{-1}$ may give rise to unacceptable taste. Also according to the FAO guidelines (Ayers and Westcot 1985), the value of 0-40 meq $\mathrm{l}^{-1}$ was established for irrigation. According to Table 3, although the sodium values of water samples were in the acceptable range for agriculture purposes in Givdari River but, its values were not suitable and acceptable for drinking usage. The results of many studies showed that sodium concentration is important when evaluating the suitability of water for agricultural purpose (Jalali 2009; Gholami and Srikantaswamy 2009; Salehi and Hosseinifard 2012; Aboyeji and Ogunkoya 2015; Hosseinifard and Aminiyan 2015). The SAR, which indicates the effect of relative cation concentration on $\mathrm{Na}^{+}$accumulation in the soil, was used for evaluating the sodicity of water (Gholami and Srikantaswamy 2009). High concentration of sodium is undesirable in water due to adsorption of $\mathrm{Na}^{+}$onto the soil cation exchange sites, could be dispersed soil aggregates, and reduced soil permeability (Liu et al. 2012).

The results showed that the maximum and minimum values of TDS corresponded to 2001 and 2002, respectively (Fig. 2d). The maximum permissible concentration of TDS for drinking water is $1000 \mathrm{mg} \mathrm{l}^{-1}$, based on taste considerations (WHO 2011). The results showed, although in 2002, 2003, 2004, 2006 and 2010 the TDS was 
Fig. 3 Ten years time trend of a cation (meq $1^{-1}$ ) and $\mathbf{b}$ anion (meq $1^{-1}$ ) values in Givdar River
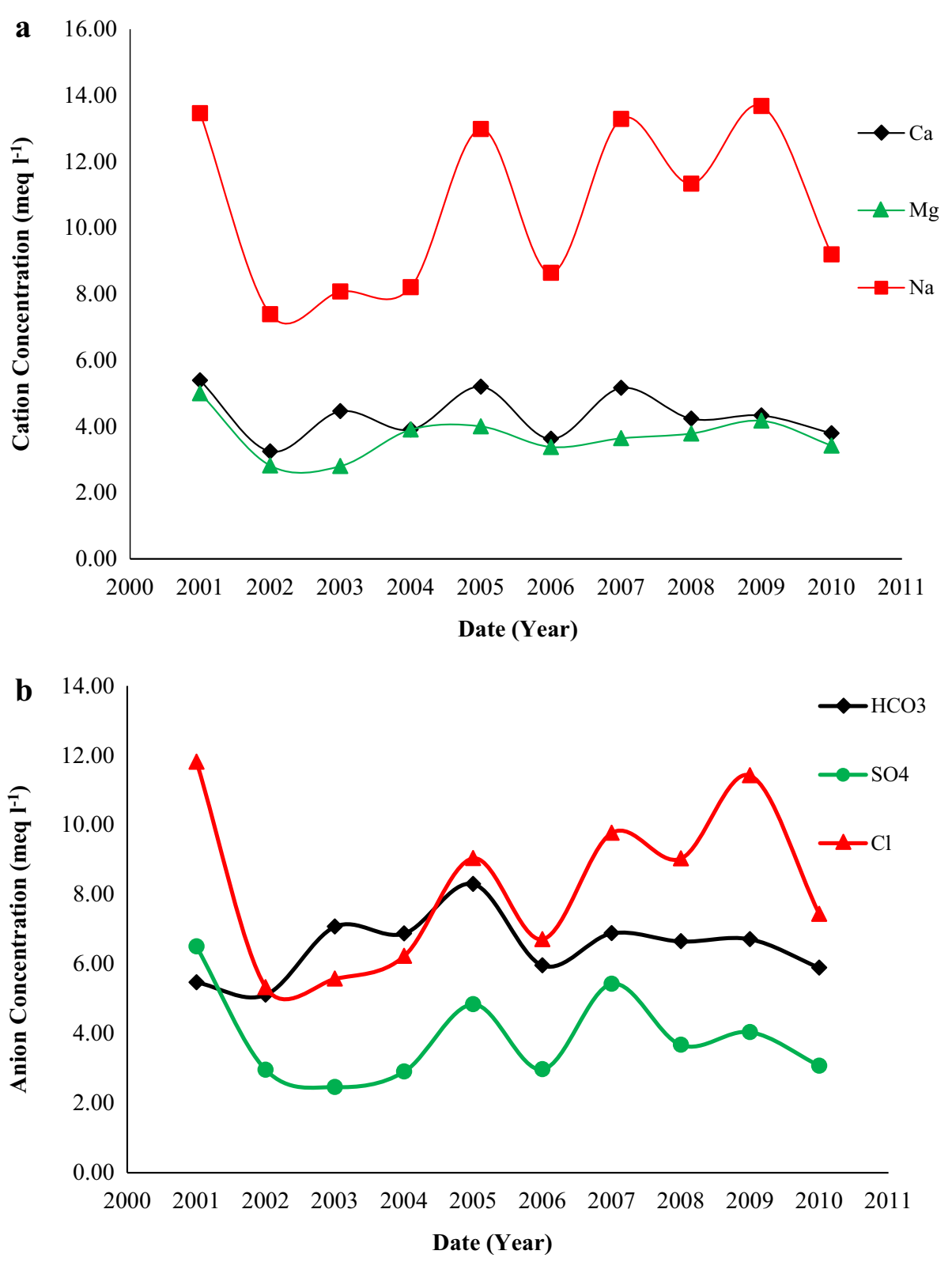

permissible for drinking but,its values were not permissible for drinking usage (WHO 2011), and according to the FAO guidelines, it is not good even for irrigation (Ayers and Westcot 1985). In this study area, the TDS values of the samples were in the range of 263-2529. The large variation in TDS values may be attributed to the variation in hydrological processes, geological formations, and the prevailing mining conditions in the region (Jalali 2010).

It was observed that in all years, the major cations concentration in water samples are in the decreasing order as $\mathrm{Na}^{+}>\mathrm{Ca}^{2+}>\mathrm{Mg}^{2+}$ (Fig. 3a). However, the anions concentration are arranged in decreasing order as $\mathrm{Cl}^{-}>$ $\mathrm{SO}_{4}{ }^{2+}>\mathrm{HCO}_{3}{ }^{+}$for 2001 , and arranged in the decreasing order $\mathrm{HCO}_{3}^{+}>\mathrm{Cl}^{-}>\mathrm{SO}_{4}{ }^{2+}$ for 2003 and 2004 but for the other years, they are arranged in decreasing order as $\mathrm{Cl}^{-}>\mathrm{HCO}_{3}{ }^{+}>\mathrm{SO}_{4}{ }^{2+}$ (Fig. 3b). Thus, it can be found that, during these years, $\mathrm{Na}$ cation and $\mathrm{Cl}$ anion were dominant except for 2003 and 2004 that $\mathrm{Na}$ cation and $\mathrm{HCO}_{3}$ anion were dominant in river water samples (Fig. 3a, b). Results obtained for the studied inland plain are comparable to those reported by earlier researches in this region (e.g., Salehi and Hosseinifard 2012; Mortazavi et al. 2014; Hosseinifard and Aminiyan 2015). For example, Salehi and Hosseinifard (2012) reported that, in water samples obtained from Rafsanjan Plain, the mean concentration of the cations was of the order $\mathrm{Na}^{+}>$ $\mathrm{Ca}^{2+}>\mathrm{Mg}^{2+}$, while that for anions was $\mathrm{Cl}^{-}>$ $\mathrm{SO}_{4}{ }^{2-}>\mathrm{HCO}_{3}{ }^{-}$. Also in some of regions of Iran such as 

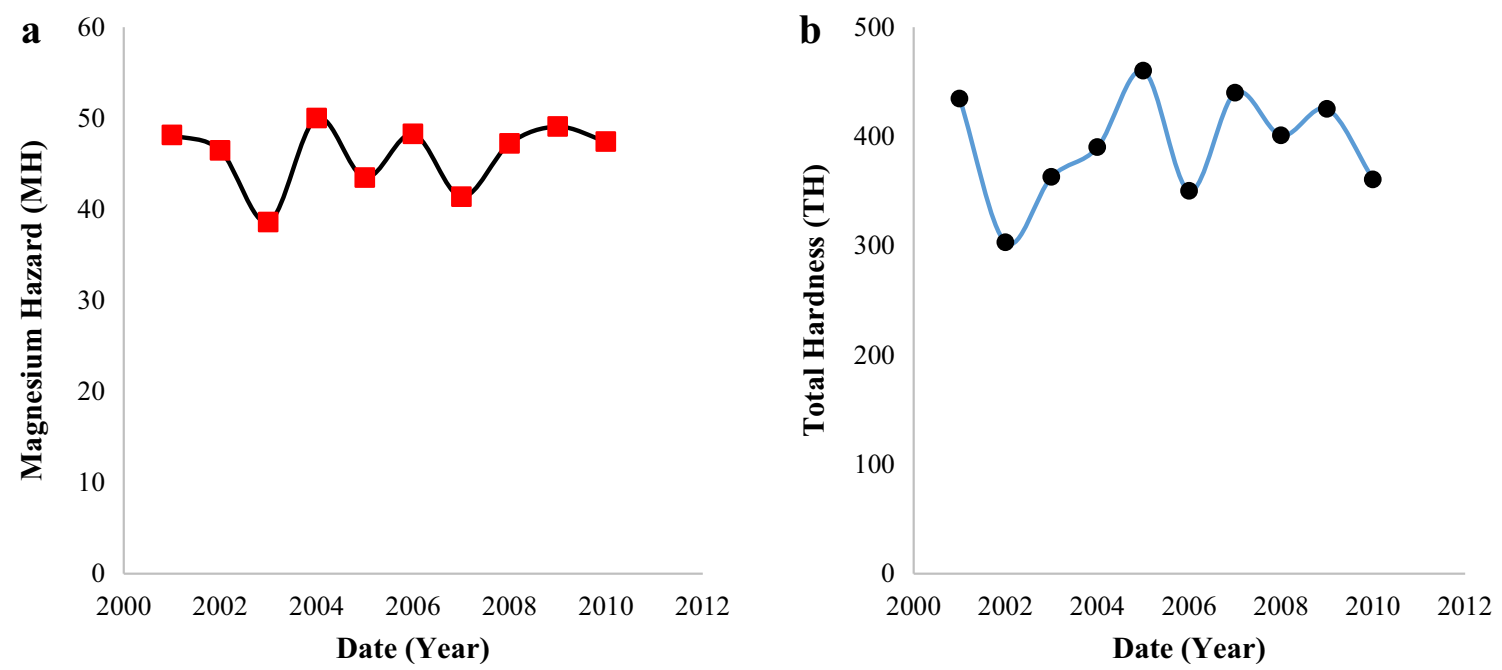

Fig. 4 Ten years time trend of a magnesium hazard (MH) and b total hardness (TH) parameters in Givdar River

Hamedan Province, the order of cation and anion abundance is reported $\mathrm{Ca}^{2+}>\mathrm{Na}^{+}>\mathrm{Mg}^{2+}>\mathrm{K}^{+}$and $\mathrm{SO}_{4}{ }^{2-}>\mathrm{HCO}_{3}^{-}>\mathrm{Cl}^{-} \geq \mathrm{CO}_{3}{ }^{2-}>\mathrm{NO}_{3}{ }^{-}$, respectively (Jalali 2010). The magnesium (Mg) in equilibrium state will adversely affect crop yield (Nagaraju et al. 2006). The magnesium hazard $(\mathrm{MH})$ of irrigation water has been proposed by Szabolcs and Darab (1964) and redefined by Raghunath (1987). The MH values exceeding 50 is considered harmful and unsuitable for agricultural purposes. In the analyzed river water samples, the $\mathrm{MH}$ values are found to range between 38.8 and 50 (Fig. 4a). The average is nearly 50 , indicating that surface water is marginally used for irrigation with little harm associated to $\mathrm{Mg}$ in the river water. The results showed that $\mathrm{Mg}$ hazard $(\mathrm{MH})$ had normal and acceptable status in Givdari River from 2001 to 2010. Hosseinifard and Aminiyan (2015) reported that $\mathrm{Mg}$ hazard $(\mathrm{MH})$ status in the some areas of Rafsanjan Plain had reached critical state, and in the other areas, the $\mathrm{MH}$ values were in excess of 50 except in Anar-Beyaz and Koshkoueiyeh areas, as in these areas, groundwater is marginally used for irrigation with little harm associated to $\mathrm{Mg}$.

Hard water results from the fact that calcium and magnesium ions in water combine with soap molecules, making it "Hard" to get suds (Liu et al. 2012). High levels of hard-water ions such as $\mathrm{Ca}^{2+}$ and $\mathrm{Mg}^{2+}$ can cause scaly deposits in plumbing, appliances, and boilers. These two ions also combine chemically with soap molecules, resulting in decreased cleansing action. The American Water Works Association (AWWA) indicates that ideal quality water should not contain more than $80 \mathrm{mg}^{-1}$ of total hardness (TH) as $\mathrm{CaCO}_{3}$ (APHA 2008). High levels of total hardness are not considered a health concern (Milovanovic 2007). On the contrary, calcium is an important component of cell walls of aquatic plants, and of the bones or shells of aquatic organisms (Jalali 2009). Magnesium is an essential nutrient for plants, and is a component of chlorophyll (Salehi and Hosseinifard 2012). Total hardness in freshwater is usually in the range of 15-375 $\mathrm{mg} \mathrm{l}^{-1}$ as $\mathrm{CaCO}_{3}$. Calcium hardness in freshwater is in the range of $10-250 \mathrm{mg} \mathrm{l}^{-1}$, often double that of magnesium hardness (5-125 $\mathrm{mg} \mathrm{l}^{-1}$ ) (WHO 2011). Based on achieved results, the minimum and maximum of $\mathrm{TH}$ related to $2002\left(140 \mathrm{mg} \mathrm{CaCO}_{3} \mathrm{1}^{-1}\right)$ and 2005 (900 mg $\mathrm{CaCO}_{3} 1^{-1}$ ), respectively (Fig. 4b). Thus, consider to the average values of TH for each year and WHO guidelines, it can be found that the TH status of Givdari River was critical for drinking usage. When water passes through or over deposits such as limestone, the levels of $\mathrm{Ca}^{2+}, \mathrm{Mg}^{2+}$, and $\mathrm{HCO}_{3}{ }^{-}$ions present in the water can greatly increase and cause the water to be classified as hard water (Aris et al. 2013). In fact, waters with more than $150 \mathrm{ppm}$ hardness cause a carbonate precipitate problem (Salehi and Hosseinifard 2012).

The high concentrations of chloride can give a salty taste to drinking water (WHO 2011). It can increase the rate of corrosion in water pipes (WHO 2011). According to the WHO guidelines, the taste thresholds for chloride are in the range of 200-300 $\mathrm{mg}^{-1}$. On average, concentrations in excess of $250 \mathrm{mg} \mathrm{l}^{-1}$ can be detected by taste (WHO 2011). The chloride concentration greater than $600 \mathrm{mg} \mathrm{l}^{-1}$ would markedly impair the potability of water. This value is the critical concentration for drinking water. In this study, the chloride values of water samples were in the range of 18-922, indicating salty water (Table 1). According to the FAO (Ayers and Westcot 1985) guidelines, the qualification of chloride is very severe making it unsuitable for drinking in the entire study areas. Chloride had high solubility in soil and remains in the soil solution, while sulphate and bicarbonate combine with calcium and magnesium, where present, to 
Table 4 Pearson's correlation between hydrochemical characteristics of water samples in Givdari River

\begin{tabular}{|c|c|c|c|c|c|c|c|c|c|c|c|}
\hline & $\mathrm{Ca}$ & $\mathrm{Mg}$ & $\mathrm{Na}$ & $\mathrm{HCO}_{3}$ & $\mathrm{SO}_{4}$ & $\mathrm{Cl}$ & TDS & $\mathrm{EC}$ & $\mathrm{pH}$ & SAR & $\mathrm{TH}$ \\
\hline $\mathrm{Ca}$ & 1 & & & & & & & & & & \\
\hline $\mathrm{Mg}$ & 0.578 & 1 & & & & & & & & & \\
\hline $\mathrm{Na}$ & 0.698 & $0.844 * *$ & 1 & & & & & & & & \\
\hline $\mathrm{HCO}_{3}$ & $0.841 * *$ & 0.708 & 0.777 & 1 & & & & & & & \\
\hline $\mathrm{SO}_{4}$ & 0.606 & 0.771 & $0.911 * *$ & 0.584 & 1 & & & & & & \\
\hline $\mathrm{Cl}$ & 0.703 & $0.894 * *$ & $0.981 * *$ & 0.750 & $0.872 * *$ & 1 & & & & & \\
\hline TDS & 0.750 & $0.885 * *$ & $0.987 * *$ & $0.824 * *$ & $0.881 * *$ & $0.986 * *$ & 1 & & & & \\
\hline $\mathrm{EC}$ & 0.751 & $0.884 * *$ & $0.988 * *$ & $0.825 * *$ & $0.882 * *$ & $0.986 * *$ & $0.999 * *$ & 1 & & & \\
\hline $\mathrm{pH}$ & -0.392 & -0.345 & -0.371 & -0.432 & -0.289 & -0.371 & -0.400 & -0.399 & 1 & & \\
\hline SAR & 0.622 & 0.754 & $0.978^{* *}$ & 0.743 & $0.887 * *$ & $0.931 * *$ & $0.949 * *$ & $0.952 * *$ & -0.335 & 1 & \\
\hline $\mathrm{TH}$ & $0.854 * *$ & $0.918 * *$ & $0.877 * *$ & $0.860 * *$ & 0.786 & $0.911 * *$ & $0.928 * *$ & $0.928 * *$ & -0.410 & 0.782 & 1 \\
\hline
\end{tabular}

Significant values at the 0.01 level are in bold

** Correlation is significant at the 0.01 level (2-tailed)

form calcium-sulphate and calcium-carbonate, which are sparingly soluble compounds. Many fruit trees and other cultivations are susceptible to injury from salt toxicity (Nganje et al. 2015). Chloride and sodium are absorbed by the roots and transported to the leaves where they accumulate. As leaf burn and leaf necrosis were observed in toxicity amounts, (Salehi and Hosseinifard 2012). Bicarbonate is also toxic. Other symptoms of toxicity include premature leaf drop, reduced growth, and reduced yield. In most cases, plants do not show clear toxicity problems until it is too late to remedy the situation (Hosseinifard et al. 2005). Chloride and sodium ions are both present in the water. Thus, it is difficult to determine whether the damage caused is due to the one or to the other (Ayers and Westcot 1985).

WHO guidelines suggested that concentrations of sulfate greater than $400 \mathrm{mg} \mathrm{l}^{-1}$ would markedly impair the potability of water; consequently, the maximum permissible value of sulfate in drinking water is $400 \mathrm{mg} \mathrm{l}^{-1}$. The sulfate concentrations in water samples were in the range of $14.4-480 \mathrm{mg} \mathrm{l}^{-1}$. The presence of sulfate in drinking water may cause bitter taste at concentrations above $250 \mathrm{mg}^{-1}$ and may contribute to the corrosion of water pipes and distribution systems.

According to the Table 4, there are statistically significant $(\alpha=0.01)$ high positive correlations between $\mathrm{Cl}$ and $\mathrm{Na}$ $(r=0.98), \mathrm{Cl}$ and $\mathrm{Mg} \quad(r=0.89)$, and $\mathrm{Cl}$ and $\mathrm{SO}_{4}$ $(r=0.87)$. Table 4 shows that TDS had good significant correlation with all cations and $\mathrm{SO}_{4}$ and $\mathrm{HCO}_{3}$ anions at the 0.01 level. Also TDS had statistically positive correlation with EC $(r=0.99)$ at the 0.01 level. Based on Table 4, correlation coefficients between total hardness $(\mathrm{TH})$ and $\mathrm{Ca}$, $\mathrm{Mg}, \mathrm{Na}, \mathrm{Cl}$, and $\mathrm{HCO}_{3}$ were statistically significant at the 0.01 level ( $r=0.85,0.91,0.87,0.91$, and 0.86), respectively. The results of many other studies also corroborated the results of present study (Rahnama and Zamzam 2013;
Mortazavi et al. 2014; Hosseinifard and Aminiyan 2015). Salehi and Hosseinifard (2012) reported high positive correlation among $\mathrm{EC}, \mathrm{Na}^{+}, \mathrm{Cl}^{-}, \mathrm{Mg}^{2+}, \mathrm{Ca}^{2+}$, and total hardness (TH). Positive correlations have been reported between the pairs of ions: $\mathrm{Cl}^{-}$and $\mathrm{Mg}^{2+}(r=0.71), \mathrm{Cl}^{-}$and $\mathrm{Na}^{+}$ $(r=0.76), \mathrm{HCO}_{3}{ }^{-}$and $\mathrm{Na}^{+}(r=0.56), \mathrm{SO}_{4}{ }^{2-}$ and $\mathrm{Mg}^{2+}$ $(r=0.76)$, and $\mathrm{SO}_{4}{ }^{2-}$ and $\mathrm{Na}^{+}(r=0.69)$ in Razan, Hamadan region (Jalali 2009). The $\mathrm{Na}-\mathrm{Cl}$ relationship has often been used to identify the mechanisms for acquiring salinity and saline intrusions in semi-arid regions (Mortazavi et al. 2014). A parallel enrichment in both ions indicate dissolution of chloride salts or concentration processes by evaporation (Jalali 2010).

The effect of sodium toxicity is not clear. However, it has been found that it may cause some direct or indirect damage to many plants and crops (Ayers and Westcot 1985). The parameters such as EC and SAR, were estimated to assess the suitability of surface water for irrigation purpose. To identify the availability of waters for agricultural purpose, the US salinity hazard diagram (after Richards 1954) has been used. According to this graph, water salinity classes for all years are grouped in C 3 class (high salinity) but water alkalinity class relates to two classes of SAR (Fig. 5). Based on salinity and alkalinity categories, the results showed that in 2002, 2003, 2004 and 2006 water falls in the category (C3-S1) and for 2001, 2005, 2007, 2008 and 2009 water falls in the category (C3S2). Although water for 2010 falls between (C3-S1) and (C3-S2) categories (Fig. 5). The water falls in (C3) class has high salinity status and from the viewpoint of sodium hazard, the water falls in S1 and S2 classes has low and medium alkalinity status, respectively. Consequently this water can be used for some agriculture purpose such as cropping tolerant plants [e.g., Pistachio (Pistacia vera L.), Barley (Hordeum vulgare), Wheat (Triticum aestivum)] 
Fig. 5 The US salinity hazard diagram (after Richards 1954) for classification of ten years water sampling in Givdari River

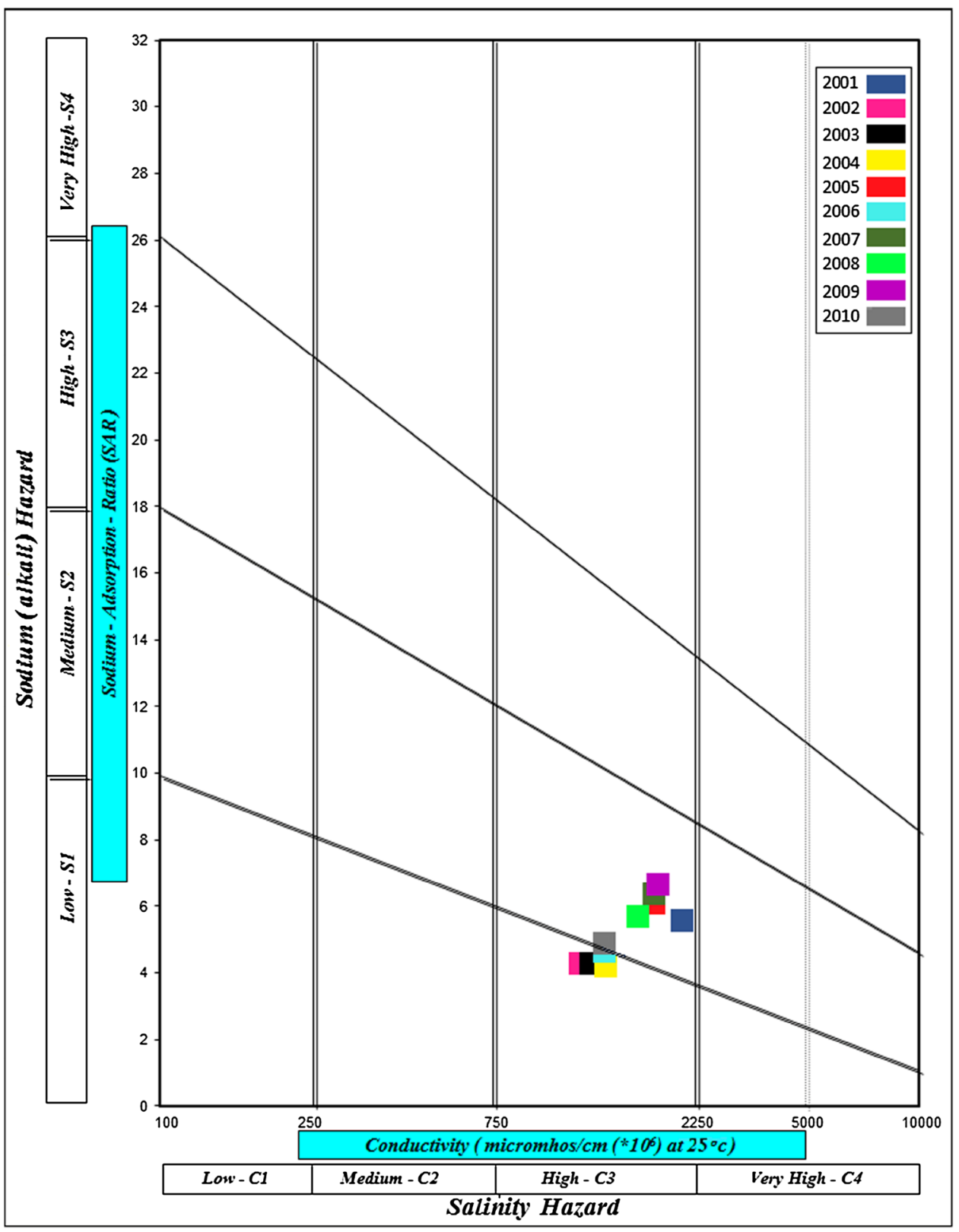

(Ayers and Westcot 1985). Zhang et al. (2012) reported that the irrigation water quality evaluation in Songnen plain, NE China, indicated that the percentage of excellent to good for irrigation was $70.45 \%$. These water samples, fell in the category $(\mathrm{C} 1-\mathrm{S} 1)$ with low salinity and sodium can be used as irrigation water directly. Hosseinifard and Aminiyan (2015) concluded that the application of water with a high SAR value and low-to-moderate salinity may be hazardous and reduce the soil infiltration rate. They also reported the salinity class was very high $(\mathrm{C} 4)$ and alkalinity (sodium hazard) classes belong to different classes of SAR in Rafsanjan plain.

The Piper diagram (1944) can be used to identify the type of water. Piper diagrams consist of three parts: two trilinear diagrams along the bottom, and one diamondshaped diagram in the middle. The trilinear diagrams illustrate the relative concentrations of cations (left diagram) and anions (right diagram) in each sample. For the purposes of a Piper diagram, the cations are grouped into three major divisions: sodium $\left(\mathrm{Na}^{+}\right)$plus potassium $\left(\mathrm{K}^{+}\right)$, calcium $\left(\mathrm{Ca}^{2+}\right)$, and magnesium $\left(\mathrm{Mg}^{2+}\right)$. The anions are similarly grouped into three major categories: bicarbonate $\left(\mathrm{HCO}_{3}{ }^{-}\right)$plus carbonate $\left(\mathrm{CO}_{3}{ }^{2-}\right)$, sulfate $\left(\mathrm{SO}_{4}{ }^{2+}\right)$, and chloride $\left(\mathrm{Cl}^{-}\right)$. The Durov Diagram (1948) is an alternative to the Piper diagram. In the two triangles, it plots the major ions as percentages of milliequivalent. The totals of both the cations and anions are set to $100 \%$, and the data points in the two triangles are projected onto a square grid which 
lies perpendicular to the third axis in each triangle. This diagram is useful in bringing out chemical relationships among waters in more definite terms. The plot reveals similarities and differences among water samples because those with similar qualities will tend to plot together as groups (Sheykhi and Moore 2012).

Chemical analysis of the Givdar River water samples and their plot on the Piper and Durov diagrams reveal that $\mathrm{Na}^{+}$and $\mathrm{Cl}^{-}$comprise the dominant cation and anion, and the majority of samples fall in the $\mathrm{Na}-\mathrm{Cl}$ facies (Figs. 6, 7). Surface water which contain numerous natural ions and polluted by industrial and human activities seriously influence agricultural utilization. Moreover, irrigation water with excessive ions also impact the environment. For example, the most common ions found in water are chloride $\left(\mathrm{Cl}^{-}\right)$and sodium $\left(\mathrm{Na}^{+}\right)$, particularly in arid and semi arid aquifers (Jalali 2009). Hosseinifard and Aminiyan (2015) also reported that according to the Piper and Durov diagrams, sodium chloride $(\mathrm{Na}-\mathrm{Cl})$ is the main water type in Rafsanjan plain. When water with high $\mathrm{Cl}^{-}$and $\mathrm{Na}^{+}$ concentrations is used for irrigation, many plants suffer from toxicity and retardation in growth, resulting in yield reduction (Seth et al. 2014; Aboyeji and Ogunkoya 2015).

Stiff diagram shows the composition of a single sample, in terms of common cations and anions, with concentration represented in electrical equivalents. In fact, this diagram investigates dominant cation and anion. Figure 8 investigates that the $(\mathrm{Na}+\mathrm{K})$ cation is the highest among the cations, while the chloride $(\mathrm{Cl})$ ion is the predominant anion in all years except for 2003 and 2004 where, bicarbonate $\left(\mathrm{HCO}_{3}\right)$ ion is the predominant anion in these years. This means that the most predominant water types in Givdari River is in order the $\mathrm{Na}-\mathrm{Cl}$ and $\mathrm{Na}-\mathrm{HCO}_{3}$. Salehi and Hosseinifard (2012) and Hosseinifard and Aminiyan (2015) reported that according to the chemical analysis of the water quality in Rafsanjan areas, the $\mathrm{Na}^{+}$cation and $\mathrm{Cl}^{-}$anion were dominant ions in water samples.

The Schoeller (1965) diagram is used to study the comparative changes in the concentrations and ratios of water quality parameters for different samples. The different water quality parameters are plotted along with their concentrations (meq $\mathrm{l}^{-1}$ ) as shown in Fig. 9. It is obvious from Fig. 9 that the highest concentration of chloride related to 2001 and 2009 and the highest concentration of sodium related to 2001, 2005, 2007, 2008 and 2009. In fact, this figure shows that $\mathrm{Na}-\mathrm{Cl}$ is almost the main water type in all years expect for 2003 and 2004 where water type is $\mathrm{Na}-\mathrm{HCO}_{3}$. The assessment and study of groundwater quality in different areas in Rafsanjan by Hosseinifard and Aminiyan (2015) revealed that according to the chemical
Fig. 6 Piper diagram for tenyears water sampling in Givdari River

\section{Piper Diagram}

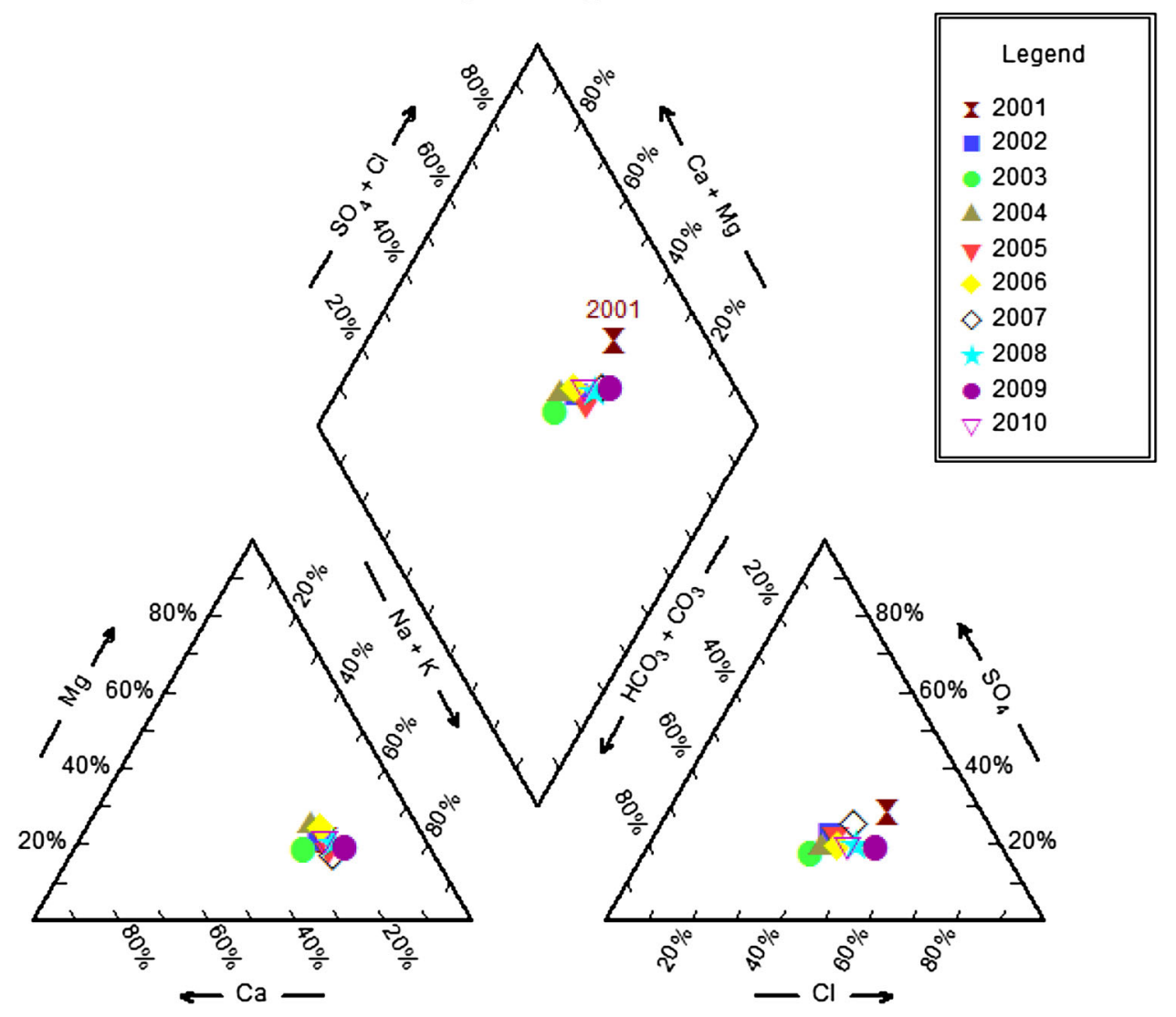


Fig. 7 Durov diagram for ten years water sampling in Givdari River

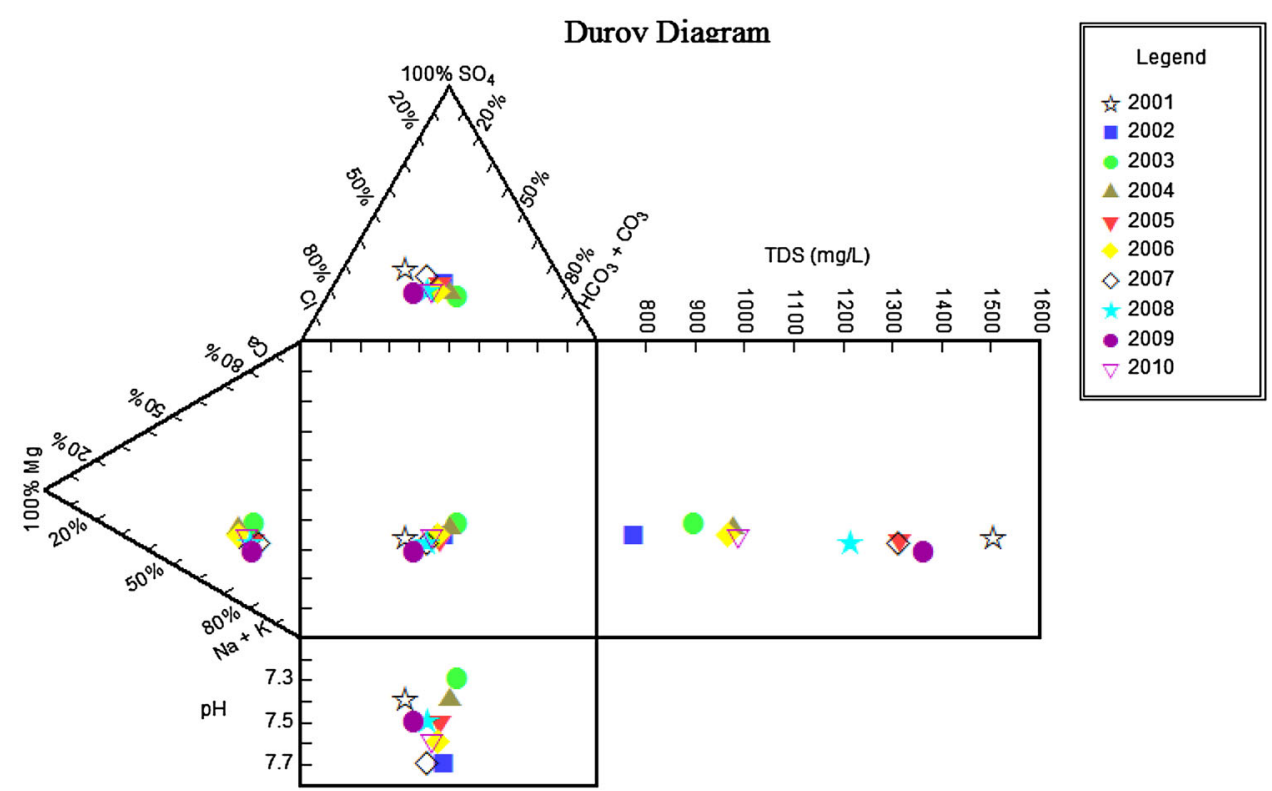

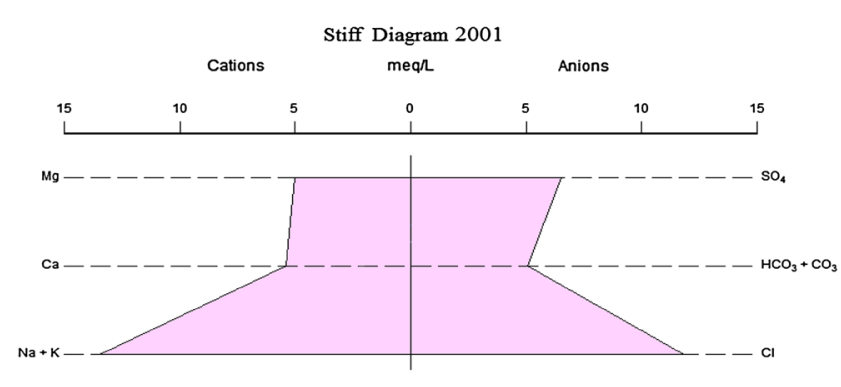

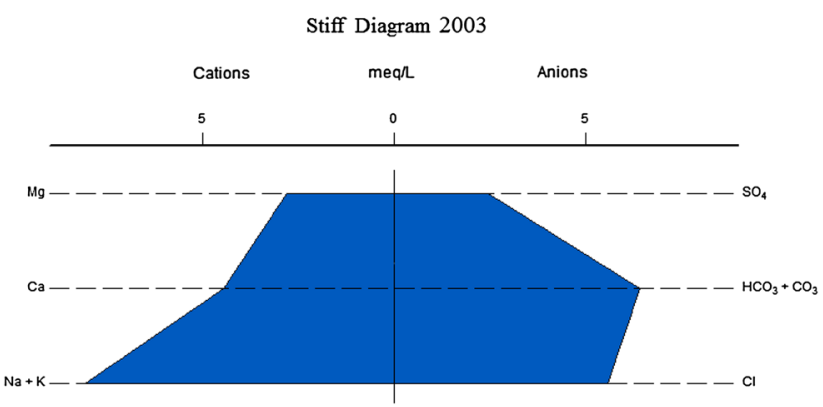

Stiff Diagram 2005

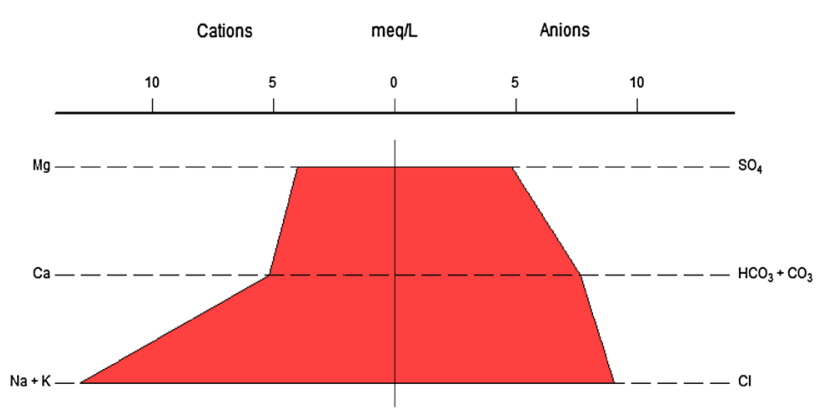

Fig. 8 Stiff diagrams for ten years water sampling in Givdari River
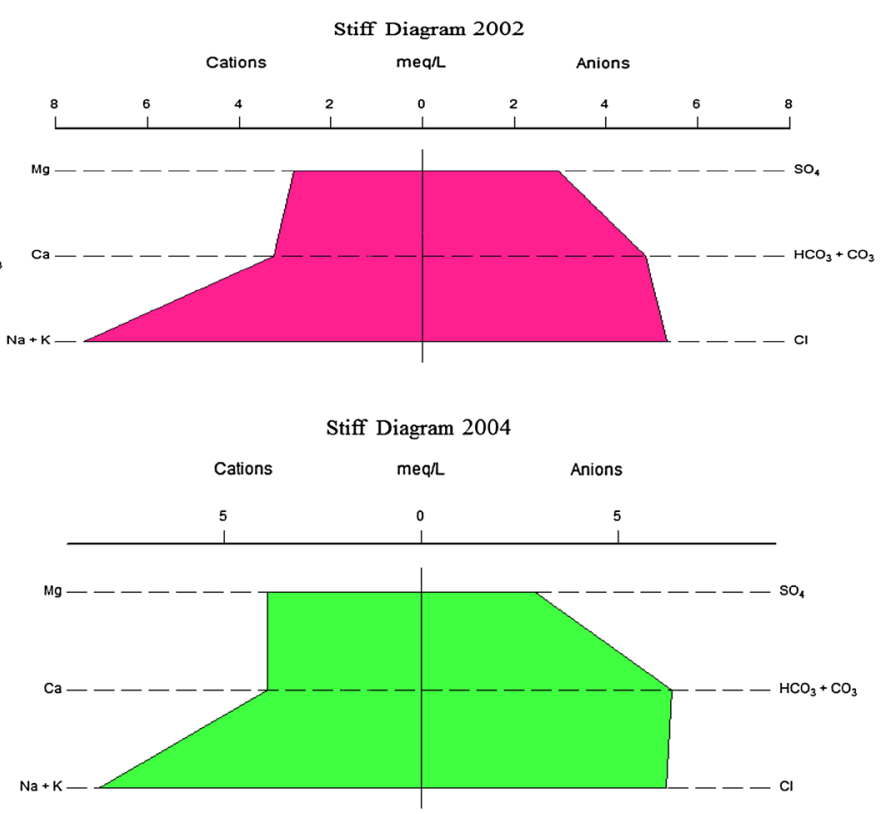

Stiff Diagram 2006

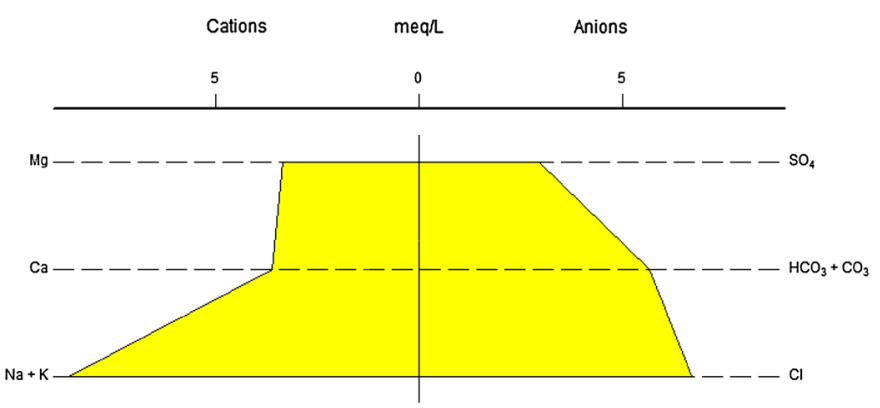



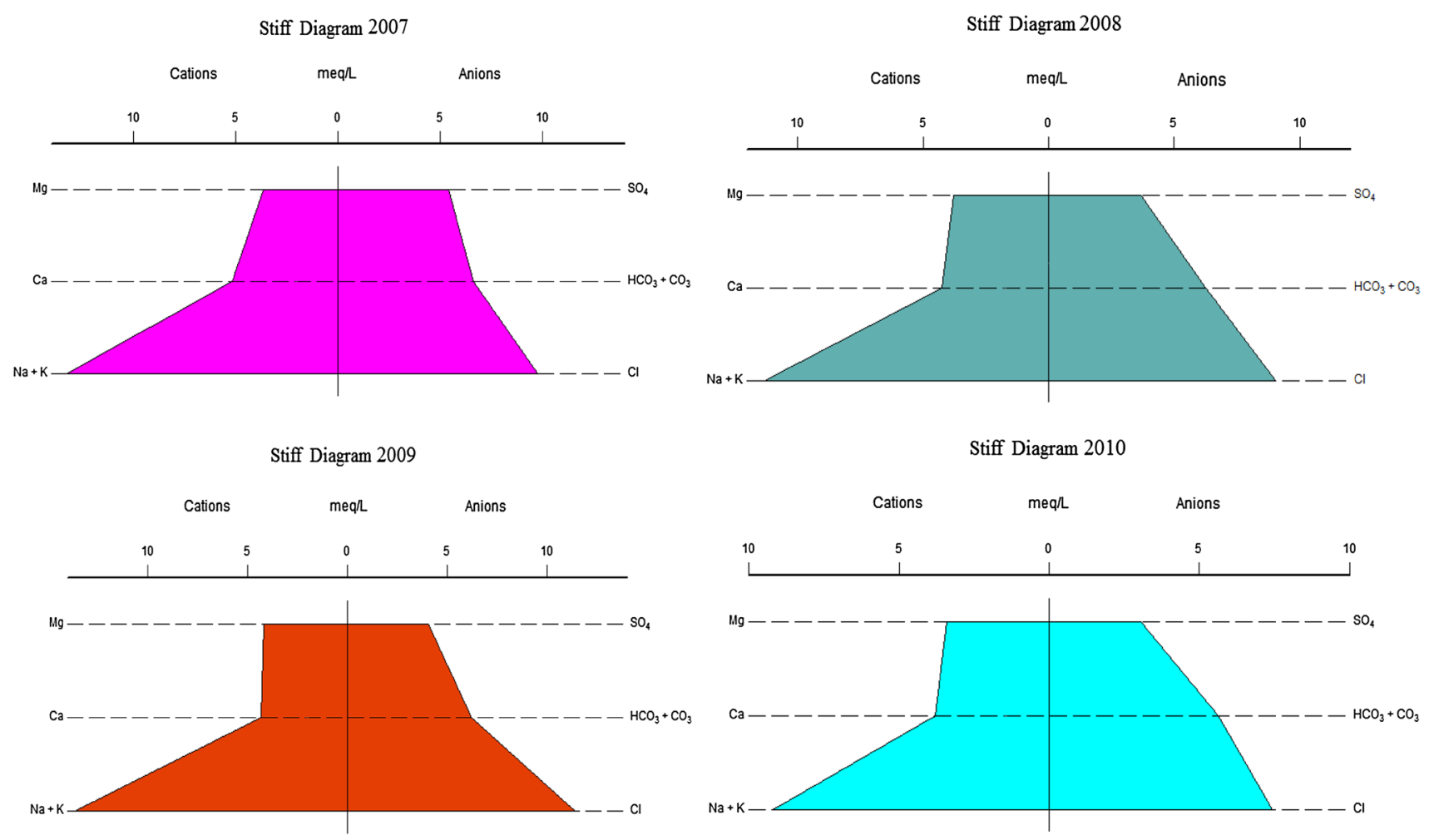

Fig. 8 continued

Fig. 9 Schoeller diagram for ten years water sampling in Givdari River

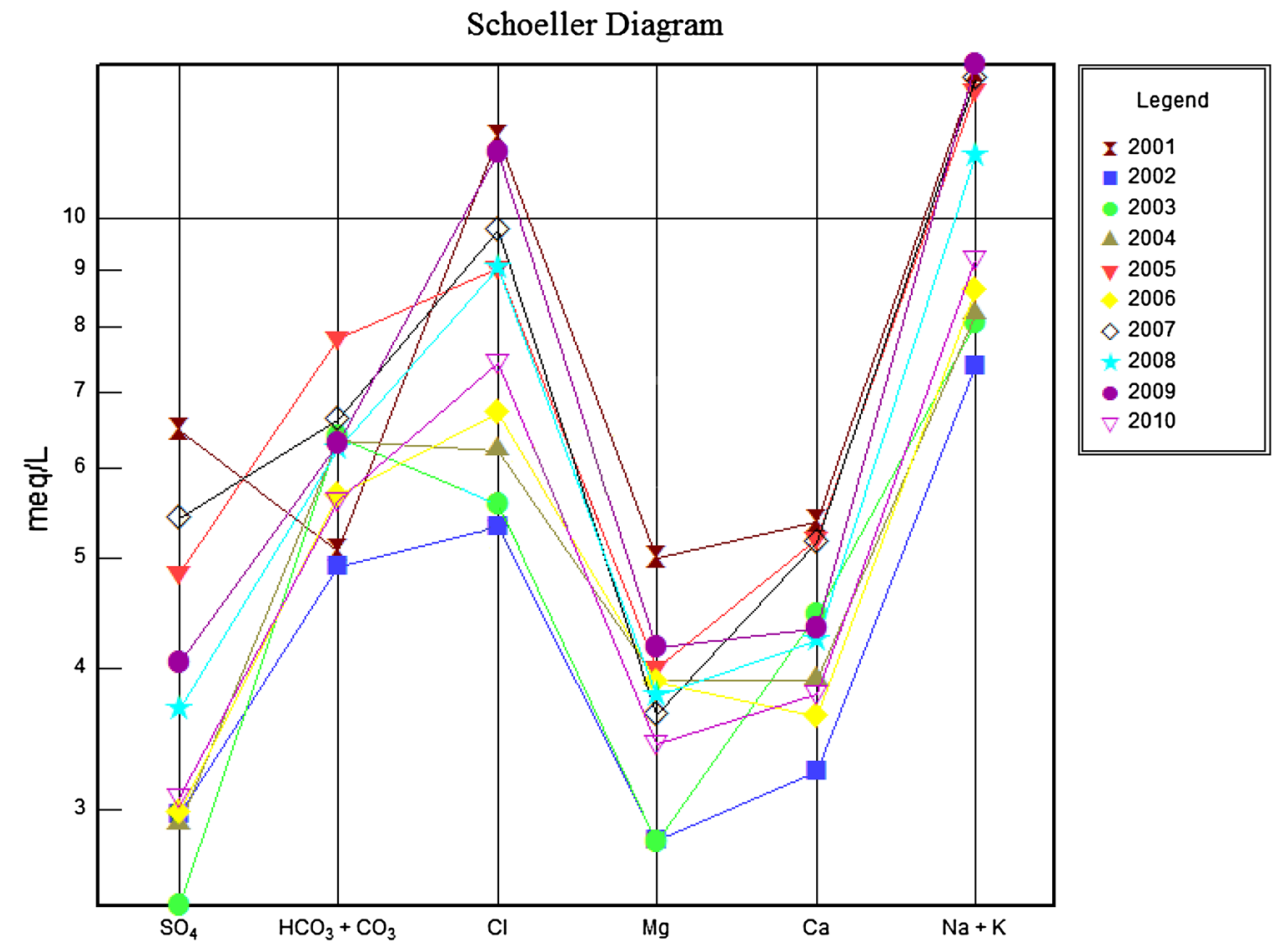

analysis of the water quality in the mentioned area and also Schoeller diagram, $\mathrm{Na}^{+}$cation and $\mathrm{Cl}^{-}$anion were the dominant ions in water samples. The assessment types of water by hydrochemical diagrams in Rafsanjan plain showed that $\mathrm{Na}-\mathrm{Cl}$ was the main and dominant type of water in this region (Hosseinifard and Aminiyan 2015) that can be related to geology and substance of Givdari River's rock and bed (Jalali 2010). The surveying of Rafsanjan 
plain's geology revealed that Salty Marl, Gypsiferous Marl, Clay and Trachyandesitic Rocks, remained from Quaternary geologic period,and were dominant in this region (Malakooti et al. 2015).

\section{Conclusion}

Water qualities of Givdari River in Rafsanjan were studied and assessed. For this purpose, the database of the monthly average values of water quality variables and parameters of Givdari River that determined by operation of local water resource, Iranian ministry of the energy at Kerman province for the period 2001-2010 were selected for this study. The EC and TDS of water samples were suitable and acceptable in Givdari River. The $\mathrm{pH}$ values were suitable and acceptable for agriculture and drinking usages in all years. It was observed that, $\mathrm{Na}$ cation and $\mathrm{Cl}$ and $\mathrm{HCO}_{3}$ anions were dominant in water samples. Consequently, $\mathrm{Na}-\mathrm{Cl}$ and $\mathrm{Na}-\mathrm{HCO}_{3}$ were two dominant and main water types in Givdari River. The results showed that Mg hazard state was normal status. The sodium values of water samples were in the acceptable range for agriculture purposes in Givdari River but, its values were not suitable and acceptable for drinking usage. According to the Pearson's correlation, high positive correlations between $\mathrm{Cl}$ and $\mathrm{Na}$, $\mathrm{Cl}$ and $\mathrm{Mg}$, and $\mathrm{Cl}$ and $\mathrm{SO}_{4}$ were observed $(\alpha=0.01)$. The TDS had good significant correlation with EC and all cations and $\mathrm{SO}_{4}$ and $\mathrm{HCO}_{3}$ anions. And also, the Total Hardness (TH) had good statistically significant correlation with all cations and some anions such as $\mathrm{Cl}$, and $\mathrm{HCO}_{3}$. The results showed that the minimum and maximum of $\mathrm{TH}$ related to 2002 and 2005, respectively. According to WHO guidelines, the results showed that the TH status of Givdari River was critical for drinking usage. Based on the salinity and alkalinity categories, the results showed that the water falls in the categories (C3-S1) and (C3-S2). According to the hydrochemistry diagrams, $\mathrm{NaCl}$ and $\mathrm{NaHCO}_{3}$ were two main water types during ten years which demand the special management for controlling salinity and sodium hazard for agriculture and drinking purposes. According to the water quality status of Givdari River, farmers are forced to use this water for agriculture practices. Hence, one way of production of crops in this region is the implant of highly tolerant plants to the salinity and sodicity (e.g., pistachio tree). Also water quality in these areas was not appropriate for drinking usage and could be harmful to health. The concentrated surface water was required for treatment to reduce the salinity and sodium hazard. The uniform management of surface water resource for irrigation and drinking uses by the government can be one of the appropriate ways to solve water-quality issues not only in Rafsanjan plain, but also in other arid and semi-arid areas.

\section{References}

Aboyeji OS, Ogunkoya OO (2015) Assessment of surface water quality of inland valleys for cropping in SW Nigeria. Appl Water Sci 1-10. doi: 10.1007/s13201-015-0309-8

Andre L, Franceschi M, Pouchan P, Atteia O (2005) Using geochemical data and modelling to enhance the understanding of groundwater flow in a regional deep aquifer, Aquitaine Basin, south-west of France. J Hydrol 305:40-62

APHA (2008) Standard methods for the examination of water and wastewater. APHA (American Public health Association) (2005) Standard methods for the examination of water and waste water, 21th edn. The American Water Works Association (AWWA) and the Water Environment Federation (WEF), Washington DC

Aris AZ, Praveena SM, Isa NM, Lim WY, Juahir H, Yusoff MK, Mustapha A (2013) Application of environmetric methods to surface water quality assessment of Langkawi Geopark (Malaysia). Environ Forensics 14(3):230-239

Awadallah AG, Yousry M (2012) Identifying homogeneous water quality regions in the Nile river using multivariate statistical analysis. Water Resour Manag 26(7):2039-2055

Ayers RS, Westcot DW (1985) Water quality for agriculture. FAO, Rome

Baghvand A, Nasrabadi T, Bidhendi GN, Vosoogh A, Karbassi A, Mehrdadi N (2010) Groundwater quality degradation of an aquifer in Iran central desert. Desalination 260:264-275

Bidhendi GN, Karbassi A, Nasrabadi T, Hoveidi H (2007) Influence of copper mine on surface water quality. Int J Environ Sci Technol 4:85-91

Bouza-Deaño R, Ternero-Rodriguez M, Fernández-Espinosa AJ (2008) Trend study and assessment of surface water quality in the Ebro River (Spain). J Hydrol 361(3):227-239

Boyacioglu H, Boyacioglu H (2007) Surface water quality assessment by environmetric methods. Environ Monit Assess 131:371-376

Dinka MO (2010) Analyzing the extents of Basaka Lake expansion and soil and water quality status of Matahara irrigation scheme, Awash Basin (Ethiopia). Ph.D. dissertation. University of Natural Resources and Applied Life Sciences, Vienna, Austria

Durov SA (1948) Natural waters and graphical representation of their composition. Dokl Akad Nauk SSSR 59:87-90

Faniran J, Ngceba F, Bhat R, Oche C (2004) An assessment of the water quality of the Isinuka springs in the Transkei region of the Eastern Cape, Republic of South Africa. Water SA 27:241-250

Gholami S, Srikantaswamy S (2009) Analysis of agricultural impact on the Cauvery river water around KRS dam. World Appl Sci J 6:1157-1169

Gowing JW, Rose DA, Ghamarnia H (2009) The effect of salinity on water productivity of wheat under deficit irrigation above shallow groundwater. Agricul Water Manag 96:517-524

Hosseinifard SJ, Aminiyan MM (2015) Hydrochemical characterization of groundwater quality for drinking and agricultural purposes: a case study in Rafsanjan Plain, Iran. Water Quality, Exposure and Health, 1-14. doi: 10.1007/s12403-015-0169-3

Hosseinifard J, Naghavi H, Jalalian A, Eghbal M (2005) Physicochemical and mineralogical properties of selected soils in the Rafsanjan pistachio area, Iran. In: The fourth international symposium on pistachio and almond

Jalali M (2009) Geochemistry characterization of groundwater in an agricultural area of Razan, Hamadan, Iran. Environ Geol 56:1479-1488

Jalali M (2010) Groundwater geochemistry in the Alisadr, Hamadan, western Iran. Environ Monit Assess 166:359-369. doi:10.1007/ s10661-009-1007-5

Jamshidzadeh Z, Mirbagheri S (2011) Evaluation of groundwater quantity and quality in the Kashan Basin, Central Iran. Desalination 270:23-30 
Liu MX, Yang JS, Li XM, Mei YU, Jin WANG (2012) Effects of irrigation water quality and drip tape arrangement on soil salinity, soil moisture distribution, and cotton yield (Gossypium hirsutum L.) under mulched drip irrigation in Xinjiang, China. J Integr Agric 11(3):502-511

Malakooti SJ, Shahhosseini M, Ardejani FD, Tonkaboni SZS, Noaparast M (2015) Hydrochemical characterisation of water quality in the Sarcheshmeh copper complex, SE Iran. Environ Earth Sci 1-20. doi: 10.1007/s12665-015-4355-1

Milovanovic M (2007) Water quality assessment and determination of pollution sources along the Axios/Vardar River, Southeastern Europe. Desalination 213:159-173

Mortazavi SM, Solaimani K, Matkan AA, Habibnejad M, Ahmadi MKZT (2014) The Effect of degradation of ground water resources on capital of Pistachio growers in Kerman province. Curr World Environ 9(3):932-939. doi:10.12944/CWE.9.3.45

Mustapha A, Aris AZ, Yusoff FM, Zakaria MP, Ramli MF, Abdullah AM, Kura NU, Narany TS (2014) Statistical approach in determining the spatial changes of surface water quality at the upper course of Kano River, Nigeria. Water Qual Expo Health 6(3):127-142. doi:10.1007/s12403-014-0117-7

Nagaraju A, Suresh S, Killham K, Hudson-Edwards K (2006) Hydrogeochemistry of waters of mangampeta barite mining area, Cuddapah Basin, Andhra Pradesh, India. Turk J Eng Environ Sci 30(4):203-219

Nganje TN, Hursthouse AS, Edet A, Stirling D, Adamu CI (2015) Assessment of the health risk, aesthetic and agricultural quality of rainwater, surface water and groundwater in the shale bedrock areas, Southeastern Nigeria. Water Qual Expo Health 7(2):153-178. doi:10.1007/s12403-014-0136-4

Nouri J, Karbassi AR, Mirkia S (2008) Environmental management of coastal regions in the Caspian Sea. Int J Environ Sci Technol $5(1): 43-52$

Palma P, Alvarenga P, Palma V, Matos C, Fernandes RM, Soares A, Barbosa IR (2010) Evaluation of surface water quality using an ecotoxicological approach: a case study of the Alqueva Reservoir (Portugal). Environ Sci Pollut Res 17(3):703-716

Pansu M, Gautheyrou J (2006) Handbook of soil analysis, mineralogical, organic and inorganic methods. Springer, p 993

Papazova P, Simeonova P (2013) Environmetric data interpretation to assess the water quality of Maritsa River catchment. J Environ Sci Health A 48(8):963-972

Piper AM (1944) A graphic procedure in the geochemical interpretation of water-analyses, Eos. Trans Am Geophys Union 25:914-928

Pradhan UK, Shirodkar PV, Sahu BK (2009) Physico-chemical characteristics of the coastal water off Devi estuary, Orissa and evaluation of its seasonal changes using chemometric techniques. Res Artic 96(9):1203-1209

Raghunath HM (1987) Ground water: hydrogeology, ground water survey and pumping tests, rural water supply and irrigation systems. New Age International
Rahnama MB, Zamzam A (2013) Quantitative and qualitative simulation of groundwater by mathematical models in Rafsanjan aquifer using MODFLOW and MT3DMS. Arab J Geosc 6(3):901-912

Richards LA (1954) Diagnosis and improvement saline and alkali soils. Agriculture handbook No. 60. United States department of agriculture, Washington DC

Salehi MH, Hosseinifard J (2012) Soil and groundwater relationships with pistachio yield in the Rafsanjan Area, Iran. Commun Soil Sci Plant Anal 43:660-671

Sawyer NN, Mc Carty PL, Parkin GF (2003) Chemistry for environmental engineering and science, 5th edn. McGraw-Hill, New York, p 752

Schoeller H (1965) Qualitative evaluation of groundwater resources. Methods and techniques of groundwater investigations and development. UNESCO, Paris, pp 54-83

Seeboonruang U (2012) A statistical assessment of the impact of land uses on surface water quality indexes. J Environ Manag 101:134-142

Seth R, Mohan M, Singh P, Singh R, Gupta VK, Dobhal R, Uniyal DP, Gupta S (2014) Assessment of seasonal variations in surface water quality of Bageshwar District, Uttarakhand, India for drinking and irrigation purposes. Proc Natl Acad Sci India Sect A Phys Sci 85(2):283-293. doi:10.1007/s40010-014-0195-8

Shakeri A, Ghoreyshinia S, Mehrabi B (2014) Surface and groundwater quality in Taftan geothermal field, SE Iran. Water Qual Expo Health 7(2):205-218. doi:10.1007/s12403-014-0141-7

Sheykhi V, Moore F (2012) Geochemical characterization of Kor river water quality, Fars Province, Southwest Iran. Water Qual Expo Health 4(1):25-38. doi:10.1007/s12403-012-0063-1

Simeonov V, Stratis JA, Samara C, Zachariadis G, Voutsa D, Anthemidis A, Sofoniou M, Kouimtzis T (2003) Assessment of the surface water quality in Northern Greece. Water Res 37:4119-4124

Singh KP, Malik A, Mohan D, Sinha S (2004) Multivariate statistical techniques for the evaluation of spatial and temporal variations in water quality of Gomti River (India): a case study. Water Res 38(18):3980-3992

Szabolcs I, Darab C (1964) The influence of irrigation water of high sodium carbonate content of soils. In: Proceedings of 8th international congress of ISSS, Trans, II, pp 803-812)

WHO (World Health Organization) (2011) Water and sanitation. Guidelines for drinking-water quality. http://apps.who.int/iris/ bitstream/10665/44584/1/9789241548151_eng.pdf. Accessed 25 Sept 2016

Zhang Y, Guo F, Meng W, Wang X-Q (2009) Water quality assessment and source identification of Daliao River basin using multivariate statistical methods. Environ Monit Assess 152:105-121

Zhang B, Song X, Zhang Y, Han D, Tang C, Yu Y, Ma Y (2012) Hydrochemical characteristics and water quality assessment of surface water and groundwater in Songnen plain, Northeast China. Water Res 46(8):2737-2748 